\title{
The late Heidegger and a post-theistic understanding of religion
}

\author{
RICO GUTSCHMIDT \\ Universität Konstanz, Fachbereich Philosophie, 78457 Konstanz, Germany \\ e-mail: ricogutschmidt@gmail.com
}

\begin{abstract}
This article explores Heidegger's later philosophy with regard to the problem of a philosophical interpretation of religious language. In what follows, I will draw upon the work of Wittgenstein and refer to the cosmological argument to read Heidegger in terms of a post-theistic understanding of religious language that avoids the shortcomings of both theistic realism and non-cognitivism. At the same time, I am proposing a new interpretation of Heidegger's later philosophy against this background. I will show that, in spite of its hermeticism, Heidegger's later philosophy has a specific relevance to philosophy of religion that still needs to be explored.
\end{abstract}

\section{Introduction}

The relation of Heidegger's philosophy to theology is a problem that remains of current interest, particularly because Heidegger's later philosophy offers some hints at an interpretation of religious language between theistic realism and non-cognitivism. According to this post-theistic reading, the talk about god neither refers to an existent being (theistic realism) nor simply expresses religious feelings (non-cognitivism). Instead, religious language can be interpreted in such a way that it describes metaphorically a cognitive content that can only be grasped metaphorically and that can alternatively be described with the spatial metaphor of the groundlessness of the world. In this article, I will argue for the plausibility of reading Heidegger as advocating this post-theistic conception.

Although there is a vast literature on Heidegger and theology (recent examples include Hemming (2002); Vedder (2007); Crowe (2008); Dillard (2008); Fischer \& Hermann (2011) ), most of it remains substantially within the perspective of theology. Against that, in this article I will focus on the questionable status of religious language from a more general, philosophical perspective. From this perspective, 
religious language is typically interpreted in two distinct ways. According to the first and prevailing interpretation, religious god-talk is referring to a divine being that literally exists, where 'exists' is understood univocally, as retaining the same sense regardless of whether it relates to this divine being or to anything else. This reading of theistic realism can be found in the long tradition of natural theology and in recent analytical philosophy of religion. According to the second interpretation, religious language is the expression of subjective states or religious feelings. This non-cognitive interpretation can be traced back at least to some readings of Schleiermacher. These two interpretations seem to form a strong alternative: Either the talk about god refers to an existent being or it is the expression of religious feelings. Nevertheless, in this article I am exploring the chances of a third way of interpreting religious language, which is inspired by the works of D. Z. Phillips. I will show that the combination of Heidegger's philosophy with a Wittgensteinian account of religion yields a post-theistic understanding of religious language that goes beyond theistic realism and non-cognitivism. With this reading, I am not only arguing for a new philosophical understanding of religious language. At the same time, I am proposing a new interpretation of Heidegger's later philosophy.

In the first part, I will give some brief background remarks on theistic realism and the cosmological argument in order to introduce the overall question of this article and its relation to Heidegger's philosophy. In the second part, then, I will draw upon the work of Wittgenstein to read Heidegger in terms of a post-theistic understanding of religion. This understanding is in line with current debates in philosophy of religion on non-metaphysical readings of religious language (Dalferth \& Hunziker (2014); Gutschmidt \& Rentsch (2016) ) and with corresponding attempts in post-modern Christian theology (as in Tracy (1981)), which in part are directly influenced by Heidegger's philosophy (as in Westphal (2001) and Schalow (2010)). Furthermore, I will refer to D. Z. Phillips, who proposes an understanding of religious god-talk that is not theistic but still not non-cognitive (see, for example, Phillips (1976)). The goal of the second part of the article is to show with the help of Wittgenstein and Heidegger that such a post-theistic understanding of religious language is plausible in general. In the third part, finally, I will explore in more detail what religious language is talking about according to this understanding. If it is neither referring to god in terms of theistic realism nor simply expresses religious feelings, something has to be said about its contents. In this regard, I will argue that religious god-talk can be interpreted as a metaphorical representation of a content that can be described alternatively as the groundlessness of the world. For this purpose, I will discuss Heidegger's notion of being (Sein) and its relation to the cosmological argument. I will argue that both notions, Heidegger's being as well as the god of the cosmological argument, can be interpreted as a metaphorical reference to the groundlessness of the world. This groundlessness can, thus, be regarded as a content of religious language that allows for a post-theistic understanding of religion beyond theism 
and non-cognitivism. In the closing section, I will briefly point out that the groundlessness of the world is relevant to philosophy and theology at the same time. Hence, with Wittgenstein's approach to religion in the background, I will argue that Heidegger's philosophy points to a common core of philosophy and theology.

\section{Heidegger, theism, and the cosmological argument}

On the one hand, the philosophical interpretation of religious language was for a long time dominated by the theistic approach of natural theology. On the other hand, there is a long tradition of criticism of theistic conceptions, which is not directed against religion. On the contrary, this criticism belongs to the religious tradition and tries to establish a deeper form of faith, as in the aniconism of the Old Testament or in negative theology. However, this criticism walks a narrow line, since, for example, Feuerbach characterizes negative theology as a special kind of atheism - not without good reason. What emerges from Feuerbach's critique is thus the question how a theistic understanding of god can be challenged without being atheistic and how such a challenge can be motivated in light of this objection.

A theistic understanding of god is the standard notion of natural theology and is at present embraced by analytical philosophy of religion. Even when analytic philosophers reject natural theology, as reformed epistemologists or fideists, they are still referring to an understanding of god in terms of theism, which particularly implies theistic realism. This understanding basically says that god literally exists somewhere, he is a highest being and has specific qualities such as omnipotence and benevolence. In a way, this understanding was already challenged by Xenophanes, but also by the aniconism in the Old Testament, by the negative henology in Plato and in Neoplatonism, and by the tradition of mediaeval negative theology. In the modern era, which was ruled by natural theology, a corresponding critique can be found in the writings of Luther, Pascal, Schleiermacher, and Kierkegaard, which influenced the accounts of Jaspers, Heidegger, and Wittgenstein. In postmodern continental thought, the works of, for example, Derrida, Levinas, and Marion are highly influenced by medieval concepts of negative theology (see Westerkamp (2006) ). However, from the perspective of analytical philosophy of religion all rejections of theism within the religious tradition can only be understood in terms of a non-cognitive interpretation of religious language. This is to say that religious language is not to be understood literally. It does not make truth claims about a being with the name of god, but is rather an expression of religious feelings, or, more precisely, of a specific attitude towards the world, as it is spelled out in Richard Hare's conception of the blik (see Hare (1955) ). From this analytical perspective, the problem of a philosophical interpretation of religious language seems only to admit a solution in terms of either theistic realism or non-cognitivism, aside from the atheistic rejection of religion altogether. 
Against that, with references to Heidegger and Wittgenstein I will establish in this article a post-theistic understanding of religious language that is neither theistic nor non-cognitive. For a start, I want to point out that Heidegger belongs to the aforementioned long tradition of the religious refusal of theistic realism. Of course, the position of theistic realism is independent of the proofs of god's existence, but Heidegger's critique is still best understood against the background of the classical refutations of these proofs. The tradition of these refutations goes from Hume and Kant through to Russell and Mackie in the twentieth century and will be illustrated here shortly with the example of the cosmological argument, which is - albeit indirectly - at the centre of Heidegger's critique. The cosmological argument also plays a crucial role in the third part of this article, which will show that the contents of the religious language in its post-theistic understanding can be described as the groundlessness of the world.

I will not discuss the details of this proof and its refutations though. For the purpose of this article, it suffices to restate the main point of its critique, which is closely related to Heidegger's overall philosophy of being. This main point simply is the assertion that it is impossible to stop the causal regress of the world's foundation with the reference to a highest being. To illustrate this point, I briefly quote three of its main protagonists. It is David Hume, who in his Dialogues concerning Natural Religion argues that god as a first cause of the world would also require a cause: 'We are still obliged to mount higher, in order to find the cause of this cause, which you had assigned as satisfactory and conclusive' (Hume (2007), 37). Kant shows in a similar way that god as a first cause would still have to admit the question about his own cause: '. . . but whence then am I? Here everything gives way beneath us ...' (Kant (1998), 574). Not least, John Leslie Mackie claims in his Miracle of Theism: 'Why is this (uncertain) god not as much in need of further explanation or support as "uncertain reality"? To say that God is introduced by definition as that which explains itself, that which terminates the regress of explanation, is again empty and useless' (Mackie (1982), 250). Of course, the tradition of natural theology has made a good case for the concept of god as a first cause without the need of further causes. Relevant arguments can be found in the works of Spinoza or Leibniz or nowadays in the positions of the analytical philosophy of religion, for example in the works of Swinburne and Plantinga. However, I will not discuss these arguments here. Instead, I will point out that Heidegger's philosophy resembles very strongly this standard refutation of the cosmological argument.

It is the overall concern of Heidegger's entire philosophy to proclaim the notion of a groundless being (Sein) or event (Ereignis), which is neither sustained by a god nor by anything else. Furthermore, he criticizes all theistic conceptions of god as ontotheology and points to the crucial fact that in criticizing this understanding of god, a 'true' religiosity can be obtained, which he describes, for example, in terms of his notion of the divine god: 'The god-less thinking which must abandon the god of philosophy, god as causa sui, is thus perhaps closer to the 
divine God' (Heidegger (1969), 72). ${ }^{1}$ In criticizing the notion of god as a causa sui, Heidegger is in line with the above-quoted standard argument against the cosmological proof of god's existence. Now, in contrast to the atheistic concern of some of the main protagonists of this counter-argument, as, for example, Russell or Mackie, Heidegger belongs to the aforementioned long tradition, which despite all its internal disparities can roughly be summarized as a religious refutation of theistic realism. Heidegger not only criticizes any theistic understanding of god, he also strengthens and emphasizes his critique with the introduction of the alternative notion of the divine god.

In what follows, I will elucidate this religious refutation of theistic realism in terms of a post-theistic understanding of religiosity. For that purpose, I will not only refer to Wittgenstein's philosophy of language, but also to Heidegger's overall concern of a groundless being. This is a crucial conception of Heidegger's entire philosophy that is not restricted to a specific period of his thinking. Therefore, I will refer to work from across Heidegger's entire corpus with particular attention to his later philosophy. ${ }^{2}$

\section{Non-referential semantics in ordinary and religious language}

Heidegger argues against the onto-theological god of the philosophers and proclaims the notion of a divine god instead. He also introduces the corresponding notions of the transition of the last god and of the divinities in the fourfold. Now, obviously, there is a tension between the refutation of the theistic interpretation of god-talk and Heidegger's own way of speaking of god or gods. What is he talking about if he refuses to refer to a god in terms of theistic realism? This tension characterizes his entire later philosophy and also leads to the central questions of this article: Can an understanding of religion without theistic realism be more than a non-cognitive interpretation of religious language? Is it possible to establish a post-theistic account of religiosity that is not just referring to a religious attitude towards the world? Since Heidegger mentions a divine god, he seems to have more in mind than a specific attitude. But is it plausible to defend a position between the seemingly strong alternative of theistic realism with its concept of god as a first cause on the one hand and a non-cognitive atheism, which might even reject religion altogether, on the other hand?

Here both Wittgenstein and Heidegger, and their respective philosophies of language, offer some help for a way of rethinking this problem. In particular, following Wittgenstein, D. Z. Phillips challenges the assumption ' . . . that realism and nonrealism are intelligible alternatives' when it comes to the interpretation of religious god-talk (Phillips (1993), 86; see also Phillips (1976), 189). Accordingly, although he refutes classical theism (realism), Phillips is not proposing a non-cognitive interpretation of religious language (non-realism) either (Phillips (1976); see also Sass (2010) and Burley (2012) ). Instead, Phillips's approach can be regarded as a form of purifying atheism that enables a deeper understanding of religiosity: 
'Atheism with respect to a God, understood in these terms, is conceptually purifying. It is a prerequisite for appreciating other religious possibilities, other forms of religious belief' (Phillips (2004), 158). For Phillips, the key to go beyond the seeming alternatives of realism and non-realism is Wittgenstein's critique of those theories of meaning that are based on the reference to objects. Hence, I will briefly illustrate Wittgenstein's respective criticism with the help of his comments on the meaning of the word 'pain' in the private language argument in the Philosophical Investigations. These comments are, of course, very well known, but I will still present them here, since I want to draw a new and striking connection to some crucial passages in Heidegger's later works that are astonishingly close to Wittgenstein's remarks.

According to Wittgenstein, the reconstruction of the meaning of the word 'pain' as a reference to a private pain sensation is untenable on closer inspection, since such a private sensation proves to be a mere chimera that plays no role in the function of language: 'If we construe the grammar of the expression of sensation on the model of "object and name", the object drops out of consideration as irrelevant' (Wittgenstein (2009), §293). This is not to say that there is no sensation of pain. However, this sensation cannot be treated as an object. This argument culminates in the famous statement about the status of this sensation: 'It's not a Something, but not a Nothing either!' (ibid., \$304). One can and even has to talk about pain as if it were an object, as in the claim: 'I have toothache.' But this claim cannot be understood as a literal reference to an actual object, as in the assertion 'I have teeth.' Following this argument, Wittgenstein rejects the objection that he would behaviouristically deny the existence of pain. But he nonetheless argues against a representational understanding of pain, according to which the word 'pain' would refer to a private sensation that exists somewhere in the human mind, conceived of as a kind of interior chamber. According to this line of thought, also the talk about god can be interpreted in a way that is neither theistic nor non-cognitive: god too is not a something, but not a nothing either. ${ }^{3}$

This general approach can also be found in Heidegger's later works, albeit implicitly. Heidegger comments almost in the words of Wittgenstein on the grammar of his talk about nothingness and being: 'The nothing is never nothing, and neither is it a something in the sense of an object' (Heidegger (2002), 85).${ }^{4}$ As Wittgenstein, Heidegger argues that such objectifications are unavoidable, but that they should not be understood literally: 'Being is not, and yet we cannot equate it with the nothing. . . . Saying "Be-ing holds sway", we again avail ourselves of, and use a naming that in language belongs to, a being' (Heidegger (1999), 201). ${ }^{5}$ According to Heidegger, this not only applies to his specific philosophical terms, but also to everyday linguistic phenomena. He elucidates the objectifying status of language by pointing to the proximity of everyday language to poetry (Heidegger (2000), 60 and passim). With reference to this proximity he argues that language generally establishes non-referential meanings as a poem does and that language is, accordingly, comprehensible without references to objects, 
although, on the surface, it does refer to objects. In particular, Heidegger discusses the 'relation of word to thing' and argues: 'This relation is not, however, a connection between the thing that is on one side and the word that is on the other' (Heidegger (1971), 66). ${ }^{6}$ Hence, despite their differing accounts of philosophy of language, for Heidegger and Wittgenstein language is ultimately not based on the schema of object and designation. Although one has to speak with the help of objectifications, one does not have to draw false conclusions about the existence of pain or god or, in Heidegger, about the existence of being and nothingness. This seems to be a trivial statement. However, it is of the utmost importance when it comes to the interpretation of religious language. A particularly striking argument in this regard is provided in Wittgenstein's remark that although one can speak meaningfully of the eye of god, which sounds like an object, one cannot speak about god's eyebrow, because it is not an object (Wittgenstein (1967), 71). This is, in the end, what the post-theistic account of religiosity is all about.

This post-theistic interpretation of religious language can be further made plausible by the fact that the meaning of religious language reveals itself only as part of the performances of religious practices, just as the meaning of the word 'pain' occurs within the shared practice of speakers in specific everyday contexts. As Wittgenstein puts it:

\footnotetext{
Obviously the essence of religion can have nothing to do with the fact that speech occurs - or rather: if speech does occur, this itself is a component of religious behavior and not a theory. Therefore, nothing turns on whether the words are true, false, or nonsensical. Neither are religious utterances figurative, for else they should be also expressible in prose. Thrusting against the limits of language? Language is not a cage. (Waismann (1965), 16)
}

In particular, the religious way of speaking is not to be understood as a parable. There is no mystery behind the language; the words say what they say and can be understood in a common religious practice. Again, this not only applies to religious language, but also to everyday and philosophical language. This is indicated in Wittgenstein's comment on the supposed cage of language which includes his own philosophical remarks about language in this consideration. The muchquoted metaphorical talk about running up against the boundaries of language cannot be understood literally, since language simply is not a cage made of wood and metal. This metaphorical description nevertheless can be understood, not as a parable that stands for something else, but very directly as what it, albeit metaphorically, says, as in the case of pain expressions. This is exactly what Blumenberg elucidates with his notion of absolute metaphors. In his Paradigms for a Metaphorology, he describes metaphors that do not have a translation into prose, but say, albeit metaphorically, just what they say (Blumenberg (2010)). A similar point can be found in the theory of metaphors in philosophy of science. Heuristic metaphors are supposed to explore new contexts in the natural sciences (Black (1962); Hesse (1963)). Also, Paul Ricoeur uses metaphors in a quite similar way (Ricoeur (1975)). Not least, according to the conceptual 
metaphor thesis by George Lakoff, metaphors generally are basic vehicles for our understanding of the world and ourselves (Lakoff \& Johnson (1980)). Although Wittgenstein denies that utterances that are not paraphrasable in prose are well described as metaphors, he still uses such utterances, as in the case of the limits of language.

Heidegger also makes use of absolute metaphors even though he maintains that these utterances should not be called metaphors. First of all, following this line of thought, it makes very good sense, contrary to the usual preconceptions, that Heidegger's language consists of a mixture of philosophical language and quasireligious or privately mythological set pieces, since, according to Wittgenstein and the respective theories of metaphors, these language games have in common the fact that each of them depends for its meaning upon particular contexts of use. Of course, they belong to different contexts, as there are significant differences between religious speech acts, religious and mythic narratives, and the philosophical language game. However, all these examples fundamentally are language games that have their meaning by virtue of them being integrated with some practice or set of practices shared by users of the language game. This particularly applies to the talk about pain, god, being, nothingness, and to the cage of language. Hence, although the practice of philosophy differs from the practice of religion, the corresponding language games basically have the same status and can thus be merged into a new language game that refers to different practices. This is what Heidegger does when he mixes the philosophical language game with religious or quasi-religious set pieces. More precisely, Wittgenstein's insight about the same status of religious talk and his own philosophical language can be found in a quite similar way in Heidegger's judgements about his talk about being: 'In saying something about being we make it into a "being" and thus cast it away' (Heidegger (1998a), 70). ${ }^{7}$ Even if something else is meant, the being can ultimately only be named as an object, just as Wittgenstein uses the metaphor of the cage to express his notion of the boundaries of language. Strictly speaking, it is even misleading to say that being would actually mean something else, because the reference to being is, as in Wittgenstein, explicitly not a talk in parables: "The saying of the thinkers does not speak in "images" and "signs"; it does not try its hand at conveyable rewritings, all of which would have to be equally inapplicable. Being itself is said' (Heidegger (2006), 267). ${ }^{8}$ Although Heidegger is explicitly denying here that he uses metaphors, he obviously uses absolute metaphors in the sense of Blumenberg. Indeed, Heidegger's notion of being is one of the paradigm examples that Blumenberg himself uses to illustrate his notion of absolute metaphors (Blumenberg (1988), 92).9 Heidegger did not know this concept, but if he knew it, he surely would have agreed that this is the way he uses language in this context.

These considerations show that there is good reason to interpret Heidegger as holding the view that religious language should neither be understood literally in a theistic way (the argument above against ontotheology, particularly against 
god as a first cause or as a causa sui respectively, will be resumed in the third part), nor as a merely poetic way of speaking, which, according to non-cognitivism, expresses a specific attitude towards the world. According to this view, religious language should instead be understood as a special practice of speaking that metaphorically refers to a very specific content that will be explored more closely in the next section. This practice of speaking is, like the talk about pain, indeed objectifying, but does not have to lead to objectifying philosophical conclusions about an existent 'being' or a theistic concept of god. ${ }^{10}$ Religious language attains its meaning solely within a shared practice of speakers, as it is generally true for language and particularly for the language of philosophy. Philosophy uses in many cases objectifying ways of speaking that are, of course, more contemporary and more systematic than the narratives of religion and that allow one to formulate philosophical theories. But still, these ways of speaking cannot be understood literally throughout. As I have shown in this section, this Wittgensteinian conception of language can be found in a strikingly similar way in the later philosophy of Heidegger, especially in its quasi-mythical talk about nothingness, being, event, and the fourfold.

To sum up, I have argued in this section with references to Wittgenstein and Heidegger that it is plausible to interpret religious language in a way that is neither theistic nor non-cognitive. However, this post-theistic interpretation of religious god-talk is still in need of a closer exploration of the specific contents of religious language. Hence, in the third part of this article I will sketch a proposal concerning the putative contents of religious language in its post-theistic reading. With references to the cosmological argument that is strongly related to Heidegger's overall philosophical concern of a groundless being, I will show that the religious language describes metaphorically a cognitive content that can alternatively be described by the spatial metaphor of the groundlessness of the world. With respect to this content, the post-theistic understanding of religious language that I am proposing here is indeed an interpretation between theism and non-cognitivism, and it also sheds a new light on the quasi-religious language in Heidegger's later philosophy and on his central notions such as being and event.

\section{The groundlessness of the world and its representation in religious language}

The proof of god's existence in the cosmological argument is a combination of philosophical and religious language already, since it shows with philosophical arguments the existence of a god who actually belongs to religious practices: et hoc omnes intelligunt Deum writes Thomas Aquinas. ${ }^{11}$ In a way, this combination of philosophical and religious language corresponds to Heidegger's combination of philosophical and mythical language and reflects the main argument of the second part of this article, which shows that the contents of religious and philosophical language cannot be fully grasped within the framework of a reference 
theory of meaning. In contrast, most utterances of religious languages and many philosophical utterances can only be understood adequately if one conceives them as special language games that have a strong metaphorical aspect. I elucidated this point with the help of Blumenberg's concept of absolute metaphors. One of the key examples of Blumenberg for this concept is the notion of the totality of the world. According to Blumenberg, the totality of the world cannot be comprehended directly, but it can still be represented metaphorically: 'Although it has been idle, ever since Kant's antinomies, to make theoretical assertions about the totality of the world, the quest for images to "stand in" for this objectively unattainable whole is by no means a trifling matter' (Blumenberg (2010), 15).

I will now discuss in more detail the metaphorical representation of the totality of the world and, more specifically, the metaphorical representation of its groundlessness with respect to Leibniz's question 'Why is there something rather than nothing?' This question constitutes the crux of the cosmological argument. But against the standard reading of this question as proving the existence of god I want to argue here that there is something wrong with this question and, hence, with the respective standard notion of god. It is Wittgenstein who points out: 'If I say "I wonder at the existence of the world" I am misusing language' (Wittgenstein (1965), 8) and 'But it is nonsense to say that I wonder at the existence of the world, because I cannot imagine it not existing' (ibid., 9). Since the nonexistence of the world is unthinkable, the talk about the wonder of the existence of the world is, strictly speaking, pointless. Similarly, Heidegger argues: 'Why are there beings at all, and not rather nothingness? . . . However deeply rooted this question may seem to be, it nevertheless lies in the forefront of the objectively represented beings. This question does not know what it asks' (Heidegger (2006), 237). ${ }^{12}$ As in Wittgenstein, the Leibniz question is classified by Heidegger as strictly speaking meaningless.

In particular, Heidegger argues that it is impossible to explain the very fact of existence with the help of beings, because, as existent beings, they would also be in need of an explanation. This would immediately lead into a regress, so that for systematic reasons the Leibniz question cannot be answered. Against that, the Leibniz question is fully justified when it is conceived of as a reference to the miracle of existence, which Heidegger also refers to as the truth of being: 'We can never understand a being through explanation and deduction from other beings. A being can only be known in terms of its grounding in the truth of be-ing' (Heidegger (1999), 164). ${ }^{13}$ To be sure, this 'grounding' is not to be understood in terms of an explanation. Rather, Heidegger wants us to see all beings against the background of the miracle of existence. This is what the Heideggerian notion of being is all about: 'Of all beings, only the human being, called upon by the voice of being, experiences the wonder of all wonders: that beings are' (Heidegger (1998c), 234). ${ }^{14}$ Astonishingly, a very similar treatment of the Leibniz question can be found in a late paper of Carl Gustav Hempel, who argues that this question cannot have an answer for logical reasons: 
But what kind of an answer would be appropriate? What seems to be wanted is an explanatory account which does not assume the existence of something or other. But such an account, I would submit, is a logical impossibility. . . . No theory, no conceptual scheme, can explain the existence of anything without assuming the existence of something. (Hempel (1973), 200)

However, Hempel also admits that the Leibniz-question is not meaningless, because 'it may well be viewed . . . as expressing a deep sense of wonder at the vast and endlessly diverse and complex universe in which we find ourselves' (ibid., 201). Hempel refers to Wittgenstein in this context (ibid., 202), who indeed speaks in a very similar way about the miracle of existence, which he first referred to as nonsense. As he puts it in his Lecture on Ethics: 'And I will now describe the experience of wondering at the existence of the world by saying: it is the experience of seeing the world as a miracle' (Wittgenstein (1965), 11). ${ }^{15}$

In this lecture, Wittgenstein also relates the experience of seeing the world as a miracle to the religious talk about god (ibid., 9-10). In this way, religious god-talk can be understood in a new and post-theistic way, namely not as an explanation of the existence of the world as in the standard reading of the Leibniz question, but as a reference to the inconceivable groundlessness of the world. In its standard reading, the Leibniz question is the starting point of the cosmological argument that I discussed briefly earlier in the article. The standard objection recited above is that the existence of the world cannot be explained by a subsisting god, since, as a being, this god again would require an explanation. Therefore, the notion of god as a first being that is supposed to explain the existence of the world simply fails. This is the same argument that I have applied in this section, with Heidegger and Hempel, to the Leibniz question. However, as the Leibniz question receives a new sense in pointing to the miracle of existence, the religious talk about god can also be reinterpreted as referring to the groundlessness of being. This post-theistic understanding of religious language can be found not only in Wittgenstein, but also in Heidegger, who claims in his idiosyncratic terminology that the Gottschaft des Gottes (godhood of gods) arises from the Wesung des Seyns (swaying of be-ing), which also represents the groundlessness of the world: 'In each case representation arrives at a higher being or at a being that is beyond beings. Here the godhood of gods never arises out of the swaying of be-ing' (Heidegger (2006), 213). ${ }^{16}$ According to Heidegger, rather than accepting apparent explanations about the fact of existence by reference to a higher being or a being that is beyond beings, that is to say by reference to god in terms of theistic realism, one has to become inständig (steadfast) in this groundlessness or, as he also calls it, in the truth of being. On my reading, this new way of being with respect to the groundlessness of the world is the main concern of Heidegger's entire philosophy. What is more, for Heidegger it is only from within this truth of being that religious language can be adequately understood. In my reformulation, this means that religious language can only be understood if it is conceived of as being related to the 
inconceivable groundlessness of the world. This is my proposal for a new interpretation of the much-quoted formula from the Letter on Humanism:

Only from the truth of being can the essence of the holy be thought. Only from the essence of the holy is the essence of divinity to be thought. Only in the light of the essence of divinity can it be thought or said what the word 'God' is to signify. (Heidegger (1998b), 267) ${ }^{17}$

To sum up, I have argued here that the talk about god can be interpreted in a posttheistic way as referring to the groundlessness of the world or to the very fact of existence respectively. The reference to the groundlessness of the world has the same metaphorical status as the talk about god and can be understood within the language game of philosophy just as the religious language can be understood within the religious language game. These language games are not separated side by side, but merge into one another as in the cosmological argument or as in Heidegger's later philosophy and both are fundamentally dependent on everyday language. Yet it is decisive here that these language games cannot be arbitrarily mixed. This is what Wittgenstein points out in his remark on god's eyebrow: Just as in this remark, religious talk about god is misunderstood if one grasps it in terms of theistic realism.

As a further differentiation, I finally want to suggest that the notion of being in Heidegger's philosophy refers to the groundlessness of the world and that Heidegger's various alternative references to god can be reconstructed as articulating the realization of the failure of the attempt to find a ground of being. This also affects the general post-theistic interpretation of religious god-talk. With Heidegger, I want to argue that this talk not only refers to the groundlessness of the world, but more precisely to the failure of the attempt to grasp a ground. To this end, I am proposing a new interpretation of the famous and notorious notion of the Vorbeigang des letzten Gottes (passing-by of the last god) in Heidegger's Contributions to Philosophy. ${ }^{18}$

To begin with, Heidegger relates the notion of the Vorbeigang to the very fact of existence: 'The grounding of Being - which is barely remembered - in the utmost being among beings proceeds from the metaphysical question about the being as such. It discovers that beings are. The fact that Being essentially occurs brushes by it' (Heidegger (1982), 208). However, the term Vorbeigang is missing in the last sentence in the English version, which translates it as brushing by. The German original of the passage goes as follows: 'Diese Begründung des kaum angedachten Seins im Seiendsten des Seienden geht gemäß der metaphysischen Frage vom Seienden als solchen aus. Sie erfährt: daß Seiendes ist. Sie wird wie in einem Vorbeigang davon gestreift, daß Sein west' (GA 67, 214). Now, according to the interpretation that I want to propose here, the experience of the miracle that being is and that Sein west can be understood as the experience of the failure of the attempt to find an explanation of being or a first ground of being respectively. This attempt inevitably leads to a regress, as it is strikingly formulated in Hume's Dialogues: 'When you go one step beyond the mundane system, you only excite an 
inquisitive humour, which it is impossible ever to satisfy' (Hume (2007), 38). This unsatisfiable inquisitiveness is described inversely in Heidegger as the refusal (Verweigerung) on the part of the event (Ereignis). There is no explanation of the very fact of existence, since every explanation would require another explanation. This failure of the attempt to explain the fact of existence leads to the experience of the miracle of existence or of the truth of being. Now, it is in the very moment of this failure that the last god passes by: 'Refusal is the highest nobility of gifting and the basic thrust of self-concealing, revelation of which makes up the originary essential sway of the truth of be-ing. Only thus does be-ing become estranging itself, the stillness of the passing of the last god' (Heidegger (1999), 285, translation modified). ${ }^{19}$ What $\mathrm{I}$ want to suggest here is that Heidegger's notion of being refers to the miracle of existence and that the metaphor of the passing-by of the last god articulates the experience of that miracle.

Moreover, I think that this line of thought can also be applied to Heidegger's later notion of the divinities in the fourfold. It is beyond the scope of this article to show this in all its details, but I think that the fourfold can be interpreted as a phenomenological-hermeneutic description of the world as a groundless event (Ereignis) and that the relation of the mortals to the divinities can be understood as the experience of the failure of the attempt to find a foundation of being. However, Heidegger yields many different phenomenological descriptions of the groundlessness of the world and, admittedly, the passing-by of the last god does not exactly describe the same experience as the notion of the divinities. Also, beyond Heidegger there are different ways for the world to be groundless. The religious experience of the groundlessness of the world surely is phenomenologically different from, for instance, the groundlessness that is experienced in Existentialism, as in Sartre's Nausea or in Camus's Stranger. With Heidegger in the background, I want to suggest here that the religious experience of the groundlessness of the world is ground-shaking and scary at first, but eventually leads to a new way of being that is positively related to its groundlessness. While the existentialist experience leads us to the abyss and abandons us there, Heidegger maintains that the experience that he has in mind does not have to lead to despair but can lead through a crisis- and conversion-like existential transformation to the experience of floating (Schweben) and to a corresponding attitude of a groundless trust, which he calls inabidingness (Inständigkeit) or releasement (Gelassenheit). This strongly resembles religious conversions and I want to suggest here that religious faith can be understood as a form of groundless trust that responds to the groundlessness of the world in a positive way. ${ }^{20}$

This is the essence of the post-theistic account of religiosity that I want to introduce here against the background of a new interpretation of Heidegger's philosophy: In a first step, the post-theistic interpretation of religious language can be explicated with Heidegger in terms of a reference to the groundlessness of the world, or, more precisely, to the experience of the failure of the attempt of grasping a ground. In a second step, then, faith can be understood in a post-theistic way as 
the attitude of a groundless trust that corresponds positively to this groundlessness (see also Gutschmidt (2016) ). This conception strongly resembles the notion of an absolute faith in Paul Tillich's Courage to Be. The absolute faith corresponds to a god above god, which, as Heidegger's divine god or last god, appears in a moment of radical doubt against a god that is understood as the ground of being. The god above god is not the god of theistic realism, but describes the groundlessness of the world, which demands a groundless trust or, in Tillich's words, a courage to be in absolute faith: "The content of absolute faith is the "God above God". Absolute faith and its consequence, the courage that takes the radical doubt, the doubt about God, into itself, transcends the theistic idea of God' (Tillich (2000), 182).

\section{Conclusion: the common core of philosophy and theology}

To sum up, I have argued in this article that Heidegger's later philosophy suggests a post-theistic understanding of religiosity and is also best understood against this background. On this reading, religious language does not refer to the god of theistic realism, but rather expresses something important about the human condition that can be described alternatively as its groundlessness. More precisely, the talk about god can be related to the experience of the failure of the attempt to find a ground. Of course, on the surface this just sounds like another version of non-cognitivism. However, although the post-theistic talk about god does not refer to a literally existent being, it stills refers to something. The crucial point is that this 'something' can only be articulated metaphorically with absolute metaphors that are unintelligible when taken literally, for example with the metaphor of the groundlessness. It cannot be reformulated straightforwardly in a theoretical statement and cannot be clearly separated from the corresponding experiences. In a way though it still is a content, albeit a 'metaphorical content', that is important for an adequate understanding of the human condition and that thus distinguishes the post-theistic reading of god-talk from noncognitivism.

This post-theistic interpretation of religious language is not only relevant to a new interpretation of Heidegger or to philosophy of religion, but also to philosophy in more general terms. The groundlessness of the world affects our selfunderstanding as finite human beings in many respects and corresponding regress problems can be found in many branches of philosophy, such as ethics, epistemology, or philosophy of language. There are voids in the centre of philosophy, and I want to suggest here that the challenge to understand these voids can be understood as a common core of philosophy and theology. It is a common core, because the classical proofs of god's existence are also dealing with regress problems and since the religious language of god represents these voids in its own way. Philosophically reformulated, this language refers to the unavailable conditions that the human being, whether he knows it or not, always relies on, and which he cannot secure on his own. The religious traditions offer appropriate 
narratives about the human condition and, as I have argued above with references to Heidegger and Wittgenstein, philosophy ultimately has to rely on specific language games as well, such as that of the 'unavailable conditions'. All in all, I think that Heidegger's later philosophy gets a new justification within this question-frame, one that is freed from the not entirely unjustified suspicion about its hermeticism and personal mythology, and that is, not least, highly relevant in spite of Heidegger's political aberrations. ${ }^{21}$

\section{References}

BAILey, Andrew (ed.) (2004) First Philosophy III: God, Mind, and Freedom: Fundamental Problems and Readings in Philosophy (Ontario: Broadview Press).

BLACK, MAX (1962) Models and Metaphors: Studies in Language and Philosophy (Ithaca: Cornell University Press).

Blumenberg, Hans (1988) Schiffbruch mit Zuschauer: Paradigma einer Daseinsmetapher (Frankfurt am Main: Suhrkamp).

Blumenberg, Hans (2010) Paradigms for a Metaphorology (Ithaca: Cornell University Press).

BRAVER, LeE (2012) Groundless Grounds: A Study of Wittgenstein and Heidegger (Cambridge MA \& London: MIT Press).

Burley, Miкel (2012) Contemplating Religious Forms of Life: Wittgenstein and D. Z. Phillips (London \& New York: Continuum).

Colony, Tracy (2008) 'The wholly other: being and the last God in Heidegger's contributions to philosophy', Journal of the British Society for Phenomenology, 39, 186-199.

Crowe, Benjamin D. (2008) Heidegger's Phenomenology of Religion: Realism and Cultural Criticism (Bloomington: Indiana University Press).

Dalferth, Ingolf \& HunziKer, Andreas (eds) (2014) Gott denken - ohne Metaphysik? (Tübingen: Mohr Siebeck).

Dillard, Peter S. (2008) Heidegger and Philosophical Atheology: A Neo-scholastic Critique (London: Continuum).

Fischer, Norbert \& Von Hermann, Friedrich-Wilhelm (eds) (2011) Die Gottesfrage im Denken Martin Heideggers (Hamburg: Meiner).

Gennaro, Ivo \& Zaccaria, Gino (2013) 'Um des Seyns willen - Heidegger und der Schritt zum Grund', in D. Schubbe, J. Lemanski, \& R. Hauswald (eds) Warum ist überhaupt etwas und nicht vielmehr nichts? Wandel und Variationen einer Frage (Hamburg: Meiner), 227-262.

Gutschmidt, Rico (2016) Sein ohne Grund: Die post-theistische Religiosität im Spätwerk Martin Heideggers (Freiburg \& Munich: Alber).

Gutschmidt, Rico \& Rentsch, Thomas (eds) (2016) Gott ohne Theismus? Neue Positionen zu einer zeitlosen Frage (Münster: Mentis).

Hare, Richard M. (1955) 'Theology and falsification', in A. Flew \& A. MacIntyre (eds) New Essays in Philosophical Theology (London: SCM Press), 99-103.

Heidegger, Martin (1969) Identity and Difference, Joan Stambaugh (tr.) (New York: Harper \& Row).

Heidegger, Martin (1971) On the Way to Language, Peter D. Hertz (tr.) (New York: Harper \& Row).

HeIDEgGer, Martin (1982) 'Nihilism and the history of being', in D. F. Krell (ed.) Martin Heidegger: Nietzsche IV. Nihilism (New York: Harper \& Row), 199-250.

Heidegger, Martin (1998a) Basic Concepts, Gary Aylesworth (tr.) (Bloomington: Indiana University Press).

Heidegger, Martin (1998b) 'Letter on "humanism"', in W. McNeill (ed.) Martin Heidegger: Pathmarks (Cambridge: Cambridge University Press), 239-276.

Heidegger, Martin (1998c) 'Postscript to "What is Metaphysics?"', in W. McNeill (ed.) Martin Heidegger: Pathmarks (Cambridge: Cambridge University Press), 231-238.

Heidegger, Martin (1999) Contributions to Philosophy, Parvis Emad \& Kenneth Maly (trs) (Bloomington: Indiana University Press).

Heidegger, Martin (2000) 'Hölderlin and the essence of poetry', in K. Hoeller (ed.) Martin Heidegger: Elucidations of Hölderlin's Poetry (New York: Humanity Books), 51-65. 
Heidegger, Martin (2002) 'The age of the world picture', in J. Young \& K. Haynes (eds) Martin Heidegger: Off the Beaten Track (Cambridge: Cambridge University Press), 57-85.

Heidegger, Martin (2006) Mindfulness, Parvis Emad \& Thomas Kalary (trs) (London: Continuum).

Hemming, Laurence P. (2002) Heidegger's Atheism: The Refusal of a Theological Voice (Notre Dame: University of Notre Dame Press).

Hempel, Carl G. (1973) 'Science unlimited?', Annals of the Japan Association for the Philosophy of Science, 4, 187-202.

Hesse, Mary (1963) Models and Analogies in Science (London: Sheed \& Ward).

Hume, David (2007) Dialogues concerning Natural Religion (Cambridge: Cambridge University Press).

Ionescu, CRIstina (2002) 'The concept of the last god in Heidegger's Beiträge: hints towards and understanding of the gift of Sein', Studia Phaenomenologica, 2, 59-95.

Kant, Immanuel (1998) Critique of Pure Reason (Cambridge: Cambridge University Press).

Kearney, Richard (2002) 'Last gods and final things: faith and philosophy', Yearbook of the Irish Philosophical Society, 71-82.

Lakoff, George \& Johnson, Mark (1980) Metaphors We Live By (Chicago: University of Chicago Press).

Mackie, John L. (1982) The Miracle of Theism (New York: Oxford University Press).

Phillips, Dewi Z. (1976) Religion without Explanation (Oxford: Blackwell).

Phillips, Dewi Z. (1993) 'On really believing', in J. Runzo (ed.) Is God Real? (London: Macmillan), 85-108.

Phillips, Dewi Z. (2004) The Problem of Evil and the Problem of God (London: SCM Press).

Ricoeur, Paul (1975) La Métaphor Vive (Paris: Le Seuil).

Sass, Hartmut von (2010) Sprachspiele des Glaubens: Eine Studie zur kontemplativen Religionsphilosophie von Dewi Z. Phillips mit ständiger Rücksicht auf Ludwig Wittgenstein (Tübingen: Mohr Siebeck).

Schalow, Frank (2010) Heidegger and the Quest for the Sacred: From Thought to the Sanctuary of Faith (Dordrecht: Kluwer).

SCHNeIder, Hans J. (2008) Religion (Berlin \& New York: de Gruyter).

Strhan, Anna (2011) 'Religious language as poetry: Heidegger's challenge', The Heythrop journal, 52, 926-938.

Tiluich, Paul (2000) The Courage to Be (New Haven \& London: Yale University Press).

Tracy, David (1981) The Analogical Imagination: Christian Theology and the Culture of Pluralism (New York: Crossroads).

VEDDER, BEN (2007) Heidegger's Philosophy of Religion: From God to the Gods (Pittsburgh: Duquesne University Press).

Waismann, Friedrich (1965) 'Notes on talks with Wittgenstein', The Philosophical Review, 74, 12-16.

WesterkAmp, Dirk (2006) Via negativa: Sprache und Methode der negativen Theologie (Munich: Fink).

WestPhal, Merold (2001) Overcoming Onto-Theology: Toward a Postmodern Christian Faith (New York: Fordham University Press).

Wittgenstein, Ludwig (1965) 'Lecture on ethics', The Philosophical Review, 74, 3-12.

Wittgenstein, Ludwig (1967) Lectures and Conversations on Aesthetics, Psychology, and Religious Belief (Berkeley \& Los Angeles: University of California Press).

Wittgenstein, Ludwig (1998) Culture and Value: A Selection from the Posthumous Remains (Oxford: Basil Blackwell).

WitTgenstein, Ludwig (2003) 'Movements of thought', in J. C. Klagge \& A. Nordmann (eds) Ludwig Wittgenstein: Public and Private Occasions (Oxford: Rowman \& Littlefield), 3-255.

Wittgenstein, Ludwig (2009) Philosophical Investigations (Chichester: Wiley-Blackwell).

\section{Notes}

1. In German: 'Demgemäß ist das gott-lose Denken, das den Gott der Philosophie, den Gott als Causa sui preisgeben muß, dem göttlichen Gott vielleicht näher' (GA 11, 70). All German quotations are reproduced according to the Gesamtausgabe (Frankfurt am Main, 1978-), citation key: GA.

2. I will not discuss Heidegger's explicit investigations of religious phenomena in his early philosophy though, since the overall concern of his philosophy of being proves to be adequate for the purpose of this study. However, this is not to say that Heidegger's early phenomenology of religion does not fit into this interpretation. On the contrary, there are strong connections between the different phases of his thinking. But it is beyond the scope of this article to discuss this in detail. 
3. The relevance of the argument on private language to a non-theistic reading of religious language is also discussed in Schneider (2008), ch. 3.

4. In German: 'Das Nichts ist niemals nichts, es ist ebensowenig ein Etwas im Sinne eines Gegenstandes' (GA 5, 113).

5. In German: 'Das Sein ist nicht und gleichwohl können wir es nicht dem Nichts gleichsetzen. . . Wir sagen: das Seyn west, und nehmen dabei doch wieder eine Nennung in Anspruch und Gebrauch, die sprachlich dem Seienden zugehört' (GA 65, 286).

6. In German: 'Dieses Verhältnis aber ist nicht eine Beziehung zwischen dem Ding auf der einen und dem Wort auf der anderen Seite' (GA 12, 159).

7. In German: 'Das Sein wird von uns, indem wir von ihm sagen, zum "Seienden" gemacht und so verworfen' (GA 51, 82-83).

8. In German: 'Das Sagen der Denker redet nicht in "Bildern" und "Zeichen” und "Chiffern”, versucht sich nicht in mittelbaren Umschreibungen, die alle gleich untriftig sein müßten. Das Sein selbst ist gesagt' (GA $66,299)$.

9. Blumenberg is not referring to the above-quoted passage, but Heidegger obviously explicates here the concept of absolute metaphors avant la lettre.

10. A similar way of interpreting religious language following Heidegger is developed in Strhan (2011).

11. 'and this everyone understands to be God' (Summa Theologica, I, Q 2, A 3), cf. Bailey (2004), 46.

12. In German: 'Warum ist überhaupt Seiendes und nicht vielmehr nichts? . . . So wurzelhaft diese Frage scheinen mag, sie hängt doch nur im Vordergrund des gegenständlich vorgestellten Seienden. Sie weiß nicht, was sie fragt' (GA 66, 267).

13. In German: 'Das Seiende können wir nie begreifen durch Erklärung und Ableitung aus anderem Seienden. Es ist nur zu wissen aus seiner Gründung in der Wahrheit des Seyns' (GA 65, 231). A recent discussion of Heidegger's relation to Leibniz's question can also be found in Gennaro \& Zaccaria (2013).

14. In German: 'Einzig der Mensch unter allem Seienden erfährt, angerufen von der Stimme des Seins, das Wunder aller Wunder: daß Seiendes ist' (GA 9, 307).

15. The groundlessness of the world in Wittgenstein and Heidegger is also discussed in Braver (2012).

16. In German: 'Jedesmal kommt das Vor-stellen zur Ansetzung eines höheren Seienden oder eines Überseienden. Niemals entspringt die Gottschaft des Gottes hier aus der Wesung des Seyns' (GA 66, 240).

17. In German: 'Erst aus der Wahrheit des Seins lässt sich das Wesen des Heiligen denken. Erst aus dem Wesen des Heiligen ist das Wesen von Gottheit zu denken. Erst im Lichte des Wesens von Gottheit kann gedacht und gesagt werden, was das Wort "Gott" nennen soll' (GA 9, 351).

18. There are many other interpretations of Heidegger's notion of the last god, see e.g. Ionescu (2002); Kearney (2002); Colony (2008).

19. In German: 'Die Verweigerung ist der höchste Adel der Schenkung und der Grundzug des Sichverbergens, dessen Offenbarkeit das ursprüngliche Wesen der Wahrheit des Seyns ausmacht. So allein wird das Seyn die Befremdung selbst, die Stille des Vorbeigangs des letzten Gottes' (GA 65, 406). Heidegger has discussed the biblical transition of god in Ex. 33, 22ff. in a class taught by Rudolf Bultmann in 1924, see Vedder (2007), 171.

20. A religious experience of floating is described by Wittgenstein. In Culture and Value, he claims that redemption 'can only come about if you no longer support yourself on this earth but suspend yourself from heaven' (Wittgenstein (1998), 39e). And in Movements of Thought, he describes faith in the following terms: 'This life must uphold you as if in suspension above this earth; that is, when you are walking on the earth, you nevertheless no longer rest on the earth, but hang in the sky, you are held from above, not supported from below' (Wittgenstein (2003), 241). In German, the first sentence is explicitly about a floating experience (Schweben): 'Dieses Leben muß Dich, gleichsam, schwebend über dieser Erde erhalten' (ibid., 240). I thank an anonymous reviewer for pointing me to these passages.

21. I thank the Deutsche Forschungsgemeinschaft (DFG) for funding my research project on Heidegger and post-theistic religiosity and two anonymous referees for their valuable and detailed comments on the manuscript. 